\title{
ANALISIS BROWNING BUAH PISANG KEPOK (Musa paradisiaca L.) SETELAH PERLAKUAN ASAM ASKORBAT DAN LIDAH BUAYA (Aloe barbadensis $L$. .)
}

\section{BROWNING ANALYSIS OF KEPOK BANANAS (Musa paradisiaca L.) AFTER THE TREATMENT OF ASCORBIC ACID AND ALOE (Aloe barbadensis $L$.)}

\author{
Ratri Mauluti Larasati $^{1 *}$, Martha Lulus Lande ${ }^{2}$, Zulkifli $^{2}$, Sri Wahyuningsih ${ }^{2}$ \\ ${ }^{1}$ Mahasiswa Jurusan Biologi FMIPA Universitas Lampung \\ ${ }^{2}$ Dosen BiologiFMIPA Universitas Lampung \\ *E-mail: ratrilarasati97@gmail.com
}

\begin{abstract}
Fruit is a necessity for most Indonesian people. Kepok banana is a climacteric fruit that can experience browning quickly. Therefore, this study was conducted to find a safe and effective material to prevent the browning process of kepok bananas. This study aims to determine the differences in the browning index, and the activity of the enzyme dehydrogenase in kepok banana cells. This study was conducted using a $2 \times 3$ factorial design. Factor $A$ is ascorbic acid with 2 concentration levels namely $0 \%(b / v)$ and $5 \%(b / v)$. Factor B is Aloe (Aloe barbadensis L.) leaf extract with 3 levels, namely $0 \%, 5 \%$, and $10 \%$. The quantitative parameters are browning index and total dissolved carbohydrate content. The qualitative parameter is dehydrogenase enzyme activity. Levene test and variance analysis were carried out with $5 \%$ real level. The results obtained were kepok bananas with treatments coloured brighter than control. Ascorbic acid and Aloe (Aloe barbadensis L.) affect the browning index and dissolved total carbohydrate content of the sample. A decrease in dehydrogenase enzyme activity happened in the ascorbic acid treatment. Conclusions obtained from the study are ascorbic acid with a concentration of 5\% can reduce the browning index of kepok banana by $31 \%$, ascorbic acid with a concentration of $5 \%$ can maintain total dissolved carbohydrate content kepok banana as much as 53\%, and Aloe extract $10 \%$ retain total dissolved carbohydrate content sample is $20 \%$.
\end{abstract}

Keywords: Kepok Banana, Aloe barbadensis L, Ascorbic Acid, Browning

Disubmit : 11 Agustus 2018; Diterima: 12 Oktober 2018; Disetujui : 04 Januari 2019;

\section{PENDAHULUAN}

Menurut hasil penelitian (Rachman, Mustika, \& Kusumawati, 2017) hubungan ketersediaan makanan terhadap perilaku konsumsi buah dan sayur menunjukkan hubungan yang positif yaitu apabila ketersediaan buah dan sayur semakin tinggi maka konsumsi buah dan sayur seseorang juga akan meningkat. Oleh karena itu proses pengawetan buah diperlukan untuk memperpanjang umur simpan buah, sehingga meningkatkan ketersediaan buah sebagai bahan pangan.

Laju respirasi buah pisang memiliki pola klimakterik. Pola klimakterik terjadi karena terjadi kenaikan jumlah $\mathrm{CO}_{2}$ yang kemudian menurun hingga buah layu. Buah pisang akan mengalami perubahan warna 
secara bertahap maupun tidak bertahap hanya dalam waktu 9 hari (Arista et al., 2017). Hal ini menunjukkan bahwa pisang adalah buah yang dapat mengalami proses pencokelatan dengan cepat.

Ekstrak lidah buaya diketahui dapat mengurangi laju respirasi buah dan efektif dalam mengurangi aktivitas enzimatik yang secara umum diketahui berperan dalam kualitas pencokelatan. Selain itu, indeks browning menunjukkan kemampuan buah yang dilapisi dengan ekstrak lidah buaya dapat mempertahankan nilai indeksnya selama kurang lebih 6 hari dibandingkan buah yang tidak diberikan perlakuan (Rosaria et al., 2015). Asam askorbat dapat menghambat proses pencokelatan non-enzimatik dan juga aktivitas enzim dehidrogenase (Husaini, Zulkifli, Lande, \& Nurcahyani, 2017).

\section{METODE PENELITIAN}

Penelitian ini telah dilaksanakan di Laboratoriun Fisiologi Tumbuhan, Jurusan Biologi, Fakultas Matematika dan Ilmu Pengetahuan Alam, Universitas Lampung dari bulan Desember 2018 sampai Januari 2019.

Alat-alat yang digunakan dalam penelitian ini adalah beaker glass, gelas ukur, pipet tetes, pipet volumetrik, erlenmeyer, tabung reaksi, rak tabung reaksi, neraca digital, mortar dan alu, kertas tissue, kertas label, karet gelang, kantong plastik, pisau, pinset, cawan petri, kapas, centrifuge, dan spektrofotometer. Bahan-bahan yang digunakan yaitu asam askorbat, daun tanaman lidah buaya (Aloe barbadensis L.) yang diperoleh di sekitar Universitas Lampung, buah pisang kepok (Musa paradisiaca L.) yang diperoleh dari pasar tradisional Bandar Lampung, aquades, $\mathrm{H}_{2} \mathrm{SO}_{4}$ pekat, fenol, dan metilen biru.

Penelitian ini dilakukan menggunakan rancangan faktorial 2x3. Faktor A adalah asam askorbat dengan 2 taraf konsentrasi yaitu 0\% (b/v) dan 5\% (b/v) (Puspaningrum, Zulkifli, Handayani, \& Lande, 2017). Faktor B adalah ekstrak daun lidah buaya (Aloe barnadensis L.) dengan 3 taraf yaitu 0\%, 5\%, dan 10\% (Purwanto \& Effendi, 2016). Dilakukan pengulangan 4 kali untuk setiap kombinasi perlakuan sehingga jumlah satuan percobaan menjadi 24. Variabel dalam penelitian ini berupa indeks browning, aktivitas enzim dehidrogenase, dan kandungan karbohidrat terlarut total. Parameter kuantitatif dalam penelitian ini adalah nilai tengah $(\mu)$ dari masing-masing variabel, sementara parameter kualitatif berupa perubahan warna yang terjadi pada uji metilen biru.

Buah pisang kepok dipilih dan diambil sebanyak 30 buah yang memiliki ukuran, berat, dan tingkat kematangan seragam. Buah pisang kepok dikupas kulitnya dan daging buah dipotong secara melintang dengan masing-masing ketebalan 2-3 mm. Kemudian diambil beberapa potongan dan ditimbang hingga mencapai berat 1 gram. Selanjutnya, potongan-potongan tersebut dibagi dalam kelompok masing-masing dan dimasukkan ke dalam larutan asam askorbat dan lidah buaya sesuai ketentuan kombinasi perlakuan. Menurut (Husaini et al., 2017) masing-masing kelompok direndam selama 15 menit. Daging buah yang sudah direndam dimasukkan ke dalam kantung plastik dan diletakkan di dalam cawan petri. Berdasarkan (Purwanto \& Effendi, 2016) kemudian semua sampel disimpan dalam suhu $4^{\circ} \mathrm{C}$ selama 7 hari.

Pengamatan indeks browning dilakukan dengan mengambil potongan buah pisang kepok dari setiap ulangan dan kontrol sebanyak 1 gram. Masing-masing digerus halus menggunakan mortar dan alu, kemudian $10 \mathrm{ml}$ aquades ditambahkan ke dalam sampel. Selanjutnya disaring menggunakan kertas saring Whatman nomor 1 dan filtrat ditampung dalam erlenmeyer. Nilai absorbansi sampel diukur menggunakan spektrofotometer dengan panjang gelombang $420 \mathrm{~nm}$ (Husaini et al., 2017).

Kandungan karbohidrat terlarut total diketahui dengan menggunakan metode fenol-sulfur. Buah pisang kepok diambil sebanyak 1 gram dan dihaluskan menggunakan mortar dan alu, kemudian ditambahkan $100 \mathrm{ml}$ aquades. Selanjutnya disaring menggunakan kertas saring Whatman nomor 1. Filtrat ditampung dengan erlenmeyer, lalu diambil sebanyak $3 \mathrm{ml}$ menggunakan pipet tetes untuk dimasukkan ke dalam tabung reaksi. Kemudian ditambahkan $3 \mathrm{ml}_{2} \mathrm{H}_{4}$ pekat dan $1 \mathrm{ml}$ fenol. Sampel dibiarkan pada suhu ruang dalam keadaan tabung terbuka hingga warna sampel berubah menjadi cokelat kemerahan. Perubahan warna ini 
menunjukkan adanya kandungan karbohidrat terlarut di dalam sampel. Nilai absorbansi diperoleh menggunakan spektrofotometer dengan panjang gelombang $490 \mathrm{~nm}$.

Aktivitas Enzin Dehidrogenase diketahui dengan menggunakan metode metilen biru (Puspaningrum et al., 2017). Sebanyak $1 \mathrm{~g}$ daging buah pisang kepok dimasukkan ke dalam tabung reaksi kemudian diberi larutan metilen biru 0,025\% sampai menutupi semua bagian buah. Tabung reaksi ditutup rapat dengan plastik dan diikat dengan karet gelang. Semua tabung reaksi diinkubasi selama 24 jam. Perubahan warna yang terjadi pada tiap perlakuan diamati. Kontrol dibuat dengan tidak memberikan perlakuan asam askorbat dan lidah buaya terhadap potongan buah pisang kepok. Hasil positif ditunjukkan dengan adanya perubahan warna pada larutan metilen biru menjadi bening. Semakin bening warna larutannya, maka aktivitas enzim dehidrogenase semakin tinggi.

Data dianalisis dengan Uji Levene dengan dan uji analisis keragaman (ANOVA) pada taraf nyata 5\%.

\section{HASIL DAN PEMBAHASAN}

Perubahan Warna Permukaan Daging Buah. Daging buah pisang yang direndam dalam larutan asam askorbat dan lidah buaya mengalami perubahan pada warna daging buah. Setelah 7 hari proses perendaman, permukaan daging buah menjadi kecokelatan. Warna kontrol terlihat lebih gelap dari pada perlakuan. Adapun warna daging buah setelah perendaman dapat dilihat pada Gambar 1.
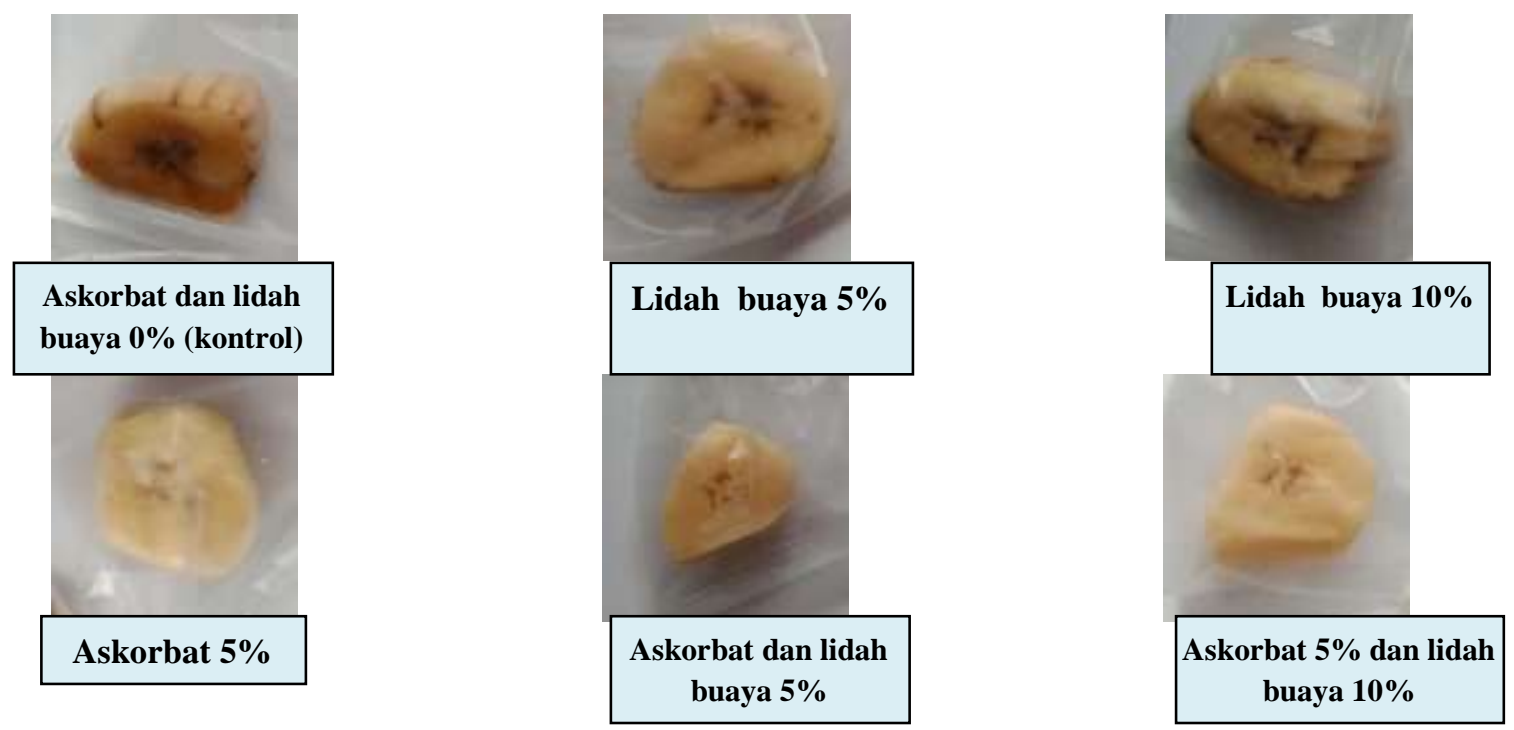

Gambar 1. Warna Permukaan Daging Buah Pisang Kepok setelah perendaman

Berdasarkan gambar tersebut dapat diketahui bahwa kontrol memiliki warna permukaan yang lebih cokelat jika dibandingkan dengan sampel pisang kepok lain yang diberi perlakuan. Hal ini menunjukkan bahwa perubahan warna cokelat pada kontrol lebih banyak dibandingkan dengan perlakuan. Menurut (Manolopoulou \& Varzakas, 2011) perubahan warna buah efektif untuk memvisualisasikan penampilan suatu produk makanan. Suhu, waktu penyimpanan, perlakuan kimia, dan interaksi diantara faktor-faktor itu memberikan efek yang cukup signifikan dalam proses perubahan warna buah menjadi cokelat.

Indeks Browning. Indeks browning buah pisang kepok sesudah diberi perlakuan asam askorbat dan lidah buaya dapat diketahui pada Tabel 1. Uji Levene pada taraf nyata 5\% (Lampiran $1 P$-value 0,39>0,05) menunjukkan bahwa ragam ke-5 populasi adalah homogen. Analisis ragam pada taraf nyata 5\% menunjukkan bahwa asam askorbat dengan atau tanpa adanya ekstrak lidah buaya berpengaruh nyata terhadap indeks browning buah pisang kepok. Pada (Lampiran $1 \mathrm{P}$-value rows $=0,0054<0,05$ ) diketahui 
bahwa indeks browning pisang kepok kontrol berbeda nyata dari indeks browning perlakuan 5\% b/v. Hal ini diduga karena konsentrasi lidah buaya yang diperlukan untuk menghambat browning pada pisang kepok lebih banyak daripada konsentrasi yang digunakan dalam penelitian ini. Menurut hasil penelitian (Purwanto \& Effendi, 2016) penggunaan larutan asam askorbat lebih efektif dalam mencegah pencokelatan daripada penggunaan lidah buaya.

Tabel 1. Nilai marginal mean lidah buaya dan asam askorbat

\begin{tabular}{lllll}
\hline Faktor & \multicolumn{4}{c}{ Ekstrak Lidah Buaya } \\
\hline Asam Askorbat & Taraf & $0 \%$ & $10 \%$ & Marginal Mean \\
& $0 \%$ & $0,517 \pm 0,085$ & $0,526 \pm 0,049$ & $0,507 \mathrm{a}$ \\
& $5 \%$ & $0,378 \pm 0,059$ & $0,368 \pm 0,089$ & $0,348 \mathrm{~b}$ \\
\hline
\end{tabular}

HSD Kolom : 0,11

HSD Baris : 0,16

Berdasarkan tabel di atas faktor asam askorbat menunjukkan nilai marginal mean kontrol 0,507a, sementara pada sampel yang diberi asam askorbat $5 \%$ memiliki nilai $0,348 \mathrm{~b}$. Sehingga dapat diketahui bahwa asam askorbat mempengaruhi pencokelatan pada buah pisang kepok. Main effect asam askorbat terhadap terhadap indeks browning buah pisang kapok ditunjukkan pada Gambar 2.

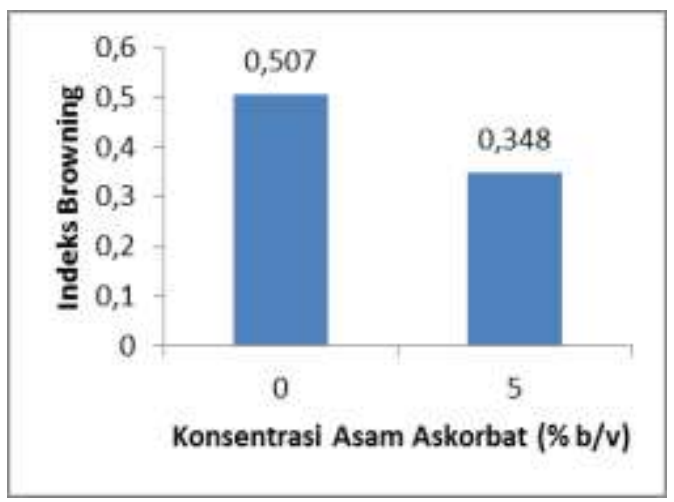

Gambar 2. Main effect konsentrasi asam askorbat terhadap indeks browning

Gambar di atas menunjukkan bahwa asam askorbat berpengaruh nyata terhadap indeks browning buah pisang kepok. Asam askorbat dengan konsentrasi 5\% dapat menurunkan indeks browning pisang kepok sebanyak $31 \%$. Hal ini sesuai dengan hasil penelitian dari (Abbasi, Akhtar, Hussain, \& Ali, 2013) bahwa asam askorbat dapat mempertahankan kualitas buah dengan mengurangi pencokelatan. Menurut (Purwanto \& Effendi, 2016) hal ini dikarenakan aktivitas PPO pada perlakuan kontrol lebih tinggi sehingga menyebabkan proses pencokelatan terjadi lebih cepat dibandingkan dengan perlakuan.

Kandungan Karbohidrat Terlarut Total. Kandungan karbohidrat terlarut total buah pisang kepok sesudah diberi perlakuan asam askorbat dan lidah buaya dapat diketahui pada Tabel 2. Uji levene pada taraf nyata 5\% (Lampiran $1 \mathrm{P}$-value 0,27 > 0,05) menunjukkan bahwa ragam ke-5 populasi adalah homogen.

Analisis ragam pada taraf nyata 5\% menunjukkan bahwa asam askorbat dengan atau tanpa adanya ekstrak lidah buaya dapat mempengaruhi kandungan karbohidrat terlarut total pada buah pisang kepok. Pada (Lampiran $1 \mathrm{P}$-value rows $=<.0001<0,05$ ) diketahui bahwa kandungan karbohidrat terlarut total pisang kepok kontrol berbeda nyata dari karbohidrat terlarut total perlakuan $5 \% \mathrm{~b} / \mathrm{v}$. 
Analisis ragam pada taraf nyata 5\% juga menunjukkan bahwa ekstrak lidah buaya dengan atau tanpa adanya asam askorbat mempengaruhi kandungan karbohidrat terlarut total buah pisang kepok. Pada (Lampiran $1 \mathrm{P}$-value columns $=0,0174<0,05$ ) menunjukkan bahwa kandungan karbohidrat terlarut total kontrol berbeda nyata dengan kandungan karbohidrat terlarut total perlakuan.

Tabel 2. Nilai marginal mean lidah buaya dan asam askorbat

\begin{tabular}{lllccc}
\hline Faktor & & \multicolumn{4}{c}{ Ekstrak Lidah Buaya } \\
\hline Asam Askorbat & Taraf & $0 \%$ & $5 \%$ & $10 \%$ & $\begin{array}{c}\text { Marginal } \\
\text { Mean } \\
\end{array}$ \\
& $0 \%$ & $0,308 \pm 0,130$ & $0,231 \pm 0,022$ & $0,697 \pm 0,136$ & $0,412 \mathrm{a}$ \\
& $5 \%$ & $0,962 \pm 0,085$ & $0,769 \pm 0,077$ & $0,885 \pm 0,087$ & $0,872 \mathrm{~b}$ \\
& Marginal & $0,635 \mathrm{a}$ & $0,500 \mathrm{ab}$ & $0,791 \mathrm{ac}$ & \\
& Mean & & & & \\
& & & &
\end{tabular}

Keterangan:

HSD baris : 0,15

HSD kolom : 0,23

Pada faktor rows dapat diketahui nilai marginal mean kontrol adalah 0,412a. Sementara pada sampel yang diberi asam askorbat $5 \%$ memiliki nilai $0,872 \mathrm{~b}$. Sehingga dapat diketahui bahwa sampel yang diberi asam askorbat 5\% memiliki kandungan karbohidrat terlarut total lebih banyak dari pada kontrol. Pada faktor column dapat diketahui nilai marginal mean kontrol adalah $0,635 \mathrm{a}$. Sementara pada pada sampel yang diberi ekstrak lidah buaya $5 \%$ memiliki nilai $0,5 \mathrm{ab}$ dan sampel yang diberi $10 \%$ ekstrak lidah buaya memiliki nilai 0,791ac. Hal tersebut menunjukkan lidah buaya berpengaruh nyata terhadap kandungan karbohidrat terlarut total dalam pisang kepok. Main effect asam askorbat terhadap terhadap kandungan karbohidrat terlarut total buah pisang kepok ditunjukkan pada Gambar 3.

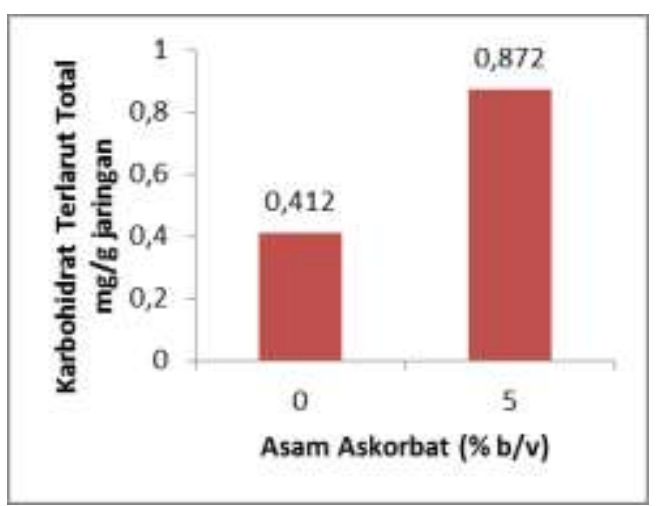

Gambar 3. Main effect konsentrasi asam askorbat terhadap kandungan karbohidrat terlarut total

Gambar di atas menunjukkan bahwa asam askorbat berpengaruh nyata terhadap kandungan karbohidrat terlarut total buah pisang kepok. Asam askorbat dengan konsentrasi 5\% dapat mempertahankan kandungan karbohidrat terlarut total pisang kepok sebanyak $53 \%$. Hasil penelitian ini sesuai dengan penelitian (Puspaningrum et al., 2017) bahwa asam askorbat dapat meningkatkan kandungan karbohidrat terlarut total. Asam askorbat dapat meningkatkan kapasitas antioksidan sehingga mempertahankan kualitas nutrisi buah (Javdani, Ghasemnezhad, \& Zare, 2013), sehingga karbohidrat di dalam buah pisang tidak terpecah oleh reaksi Maillard. 
Main effect ekstrak lidah buaya terhadap terhadap kandungan karbohidrat terlarut total buah pisang kepok ditunjukkan pada gambar 4.

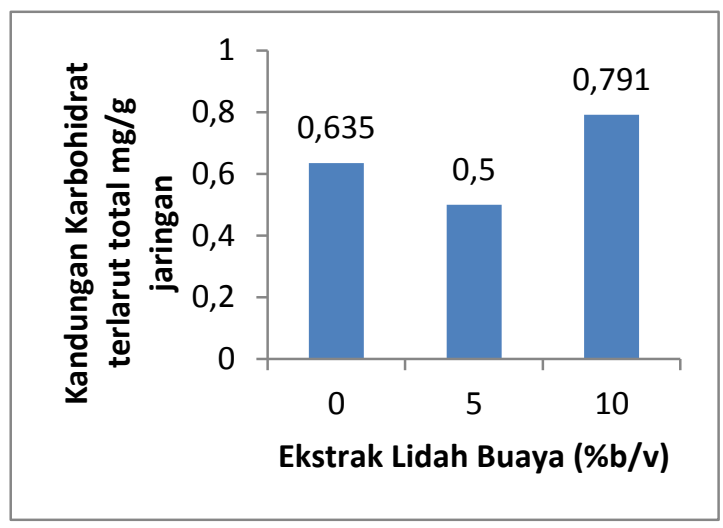

Gambar 4. Main effect ekstrak lidah buaya terhadap kandungan karbohidrat terlarut total

Gambar di atas menunjukkan bahwa ekstrak lidah buaya 5\% berpengaruh nyata terhadap kandungan karbohidrat terlarut total buah pisang kepok. Ekstrak lidah buaya dengan konsentrasi 5\% dapat menurunkan kandungan karbohidrat terlarut total buah pisang kepok sebanyak $21 \%$. Hal ini terjadi diduga karena ekstrak lidah buaya dengan konsentrasi 5\% tidak cukup banyak untuk menghambat reaksi Maillard. Menurut (Hu et al., 2016) reaksi pencokelatan non-enzimatik terjadi selama proses perubahan warna buah menjadi cokelat, mekanisme yang menyebabkan hal ini terjadi berhubungan dengan perubahan dalam pengurangan molekul gula dan asam amino. Sementara ekstrak lidah buaya $10 \%$ berpengaruh nyata terhadap kandungan karbohidrat terlarut total buah pisang kepok. Ekstrak lidah buaya dengan konsentrasi 10\% dapat mempertahankan kandungan karbohidrat terlarut total buah pisang kepok sebanyak $20 \%$ diduga karena lapisan lidah buaya menghambat proses senesen pada buah pisang kepok sehingga menunda perombakan karbohidrat menjadi gula (Sridevi, Bhaskar, Subbaramamma, \& Suneetha, 2018).

Aktivitas Enzim Dehidrogenase. Aktivitas enzim dehidrogenase pada buah pisang kepok setelah diberi perlakuan asam askorbat dan ekstrak lidah buaya dan diinkbasi dalam suhu ruang selama 24 jam dapatdiamati pada Gambar 5.

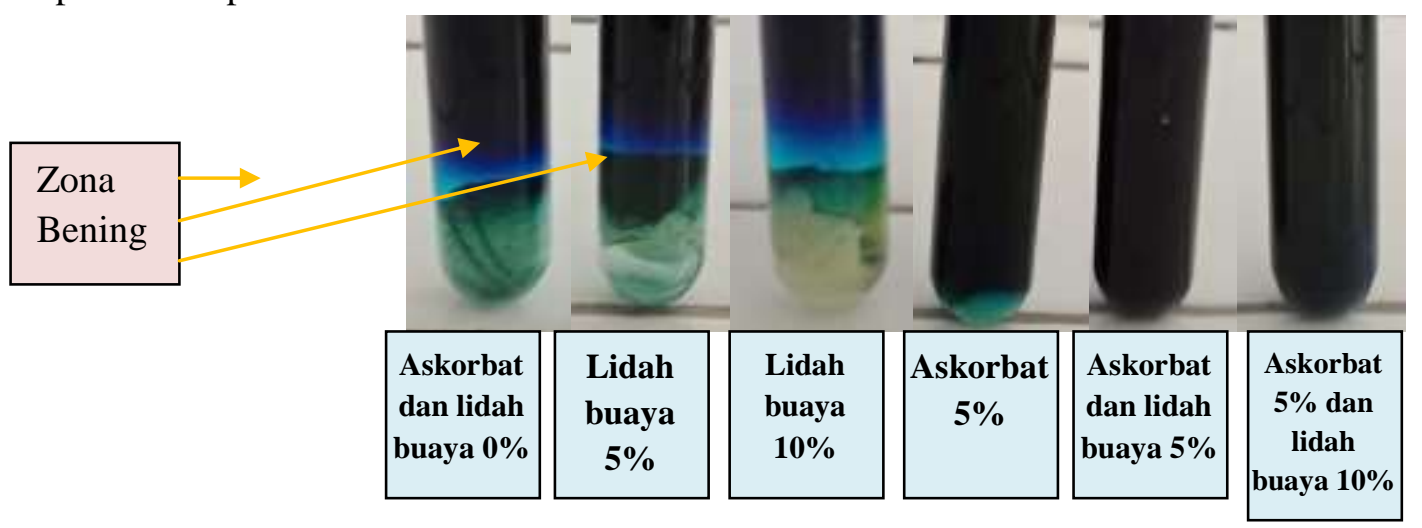

Gambar 5. Aktivitas enzim dehidrogenase buah pisang kepok

Berdasarkan hasil pengamatan sampel dalam methylene blue, terlihat bahwa terdapat zona bening pada kontrol, perlakuan lidah buaya 5\%, dan lidah buaya 10\%. Pada ketiga sampel tersebut tidak dilakukan penambahan asam askorbat, sementara perlakuan askorbat 5\%, askorbat 5\% dan lidah buaya 5\%, serta askorbat $5 \%$ dan lidah buaya $10 \%$ tidak menunjukkan adanya zona bening. 
Menurut (Manolopoulou \& Varzakas, 2011) enzim dehidrogenase tidak dapat bekerja pada kondisi asam dimana enzim tersebut berperan dalam siklus krebs, sehingga siklus krebs pada sampel yang diberi asam askorbat mengalami penurunan.

\section{KESIMPULAN [DAN SARAN}

Berdasarkan hasil penelitian yang dilakukan maka diperoleh kesimpulan asam askorbat dengan konsentrasi 5\% dapat menurunkan indeks browning pisang kepok sebanyak $31 \%$ dan mempertahankan kandungan karbohidrat terlarut total pisang kepok sebanyak $53 \%$. Ekstrak lidah buaya 10\% mempertahankan kandungan karbohidrat terlarut total buah pisang kepok sebanyak $20 \%$.

Saran yang diajukan untuk penelitian selanjutnya yaitu perlu dilakukan penelitian lanjutan mengenai uji kandungan gula pereduksi dan kandungan karbohidrat terlarut total secara kuantitatif.

\section{DAFTAR PUSTAKA}

Abbasi, N. A., Akhtar, A., Hussain, A., \& Ali, I. 2013. Effect Of Anti-Browning Agents on Quality Changes of Loquat [ Eriobotrya japonica ( Thunmb .) Lindley ] Fruit after Harvest. Journal of Botany, 45(4), 1391-1396.

Arista, M. L., Widodo, W. D., Suketi, K., Agronomi, D., Pertanian, F., \& Bogor, I. P. 2017. Penggunaan Kalium Permanganat sebagai Oksidan Etilen untuk Memperpanjang Daya Simpan Pisang Raja Bulu. Buletin Agrohorti, 5(3), 334-341.

Hu, M., Peng, W., Liu, Y., Yan, D., Chen, X., \& Wu, C. 2016. Maillard reaction induces changes in saccharides and amino acids during stir-baking of areca nuts. Tropical Journal of Pharmaceutical Research, 15(October), 2107-2112.

Husaini, O., Zulkifli, Lande, M. L., \& Nurcahyani, E. 2017. Karakterisasi Bahan Anti Browning dari Ekstrak Air Buah Jambu Batu (Psidium guajava Linn) pada Buah Apel Malang (Malus sylvestris (L.) Mill). Jurnal Pertanian Terapan, 17, 85-92.

Javdani, Z., Ghasemnezhad, M., \& Zare, S. 2013. A comparison of heat treatment and ascorbic acid on controlling enzymatic browning of fresh-cuts apple fruit. Journal of Agriculture and Crop Sciences.

Manolopoulou, E., \& Varzakas, T. 2011. Effect of Storage Conditions on the Sensory Quality, Colour and Texture of Fresh-Cut Minimally Processed Cabbage with the Addition of Ascorbic Acid, Citric Acid and Calcium Chloride. Journal of Food and Nutrition Sciences, 2011(November), 956-963. https://doi.org/10.4236/fns.2011.29130

Purwanto, Y. A., \& Effendi, R. N. 2016. Penggunaan Asam Askorbat dan Lidah Buaya untuk Menghambat Pencokelatan pada Buah Potong Apel Malang. Jurnal Keteknikan Pertanian, 4, 203-210. Retrieved from http://journal.ipb.ac.id/index.php/jtep

Puspaningrum, D. A., Zulkifli, Handayani, T. T., \& Lande, M. L. 2017. Pengaruh Penambahan Asam Askorbat Terhadap Proses Non-Enzimatik Browning Jus Buah Salak Pondoh (Salacca zalacca Gaertn.)e. Jurnal Penelitian Pertanian Terapan, (2017).

Rachman, B. N., Mustika, I. G., \& Kusumawati, I. G. A. W. 2017. Faktor yang berhubungan dengan perilaku konsumsi buah dan sayur siswa SMP di Denpasar. Jurnal Gizi Indonesia, 6(1).

Rosaria, G., Alberio, A., Muratore, G., Licciardello, F., Giardina, G., \& Spagna, G. 2015. Aloe vera extract as a promising treatment for the quality maintenance of minimally-processed table grapes. Journal of Food Science and Technology, 35(2), 299-306. 
Larasati, dkk : Analisis Browning Buah Pisang Kepok (Musa Paradisiaca L.) Setelah Perlakuan Asam Askorbat Dan

Sridevi, P., Bhaskar, V. V., Subbaramamma, P., \& Suneetha, D. R. S. 2018. Effect of Aloe vera Gel on the Physiological, Biochemical and Quality Parameters of Pomegranate Arils cv . ' Bhagwa .' Journal of Current Microbiology and Applied Sciences, 7(01), 1757-1766. 